\title{
Psalm 5 and the polarity between those who may stand before Yahweh and those who may not
}

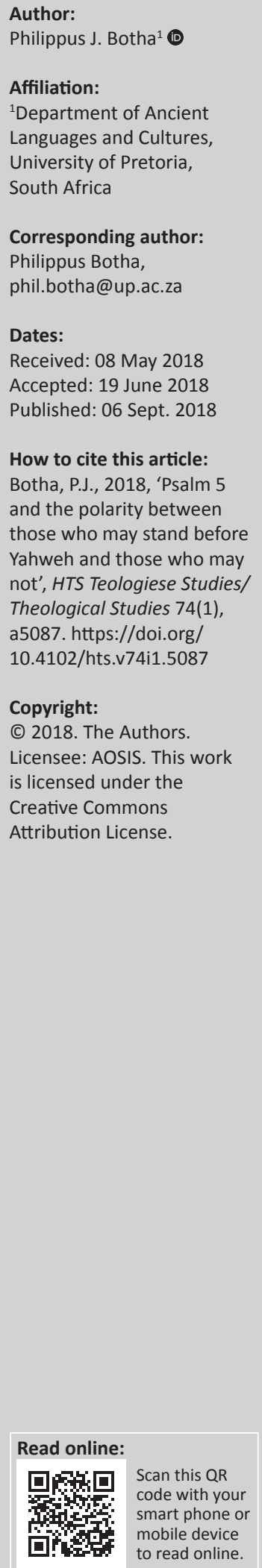

Psalm 5 is often described as an example of a prayer of someone who has been falsely accused of wrongdoing. Based on the contents of the middle part of the psalm, its wisdom features and especially the parallels it forms with Psalm 1, it is argued in this article that the editors of the Psalter attempted to present the psalm as a prayer of David at the time of his flight from Absalom. In this prayer of the endangered king, he (prophetically) pronounced judgement on the actions and attitudes of his opponents and respectfully entrusted himself to the care of Yahweh. In its literary context, the psalm was therefore probably meant to censure arrogant and irreligious compatriots of the editors, because they exploited fellow Jews, and also to provide hope and encouragement to those exploited members of the in-group.

\section{Introduction}

Psalm 5 is often considered to constitute a prayer for help in a legal dispute where the suppliant has been falsely accused of some or other offence and now strives for divine vindication. ${ }^{1}$ From the בקר אערך־לך) ', it is typically inferred in such an interpretation ${ }^{2}$ that the suppliant is in the temple precinct, bringing (or planning to bring) a sacrifice and reciting this psalm as a prayer for help from Yahweh. From the promised access to the temple (vv. 5-7) he draws hope (v. 8) and prays for a judgement from God in his favour 'in the morning' (vv. 9-11). According to this interpretation, the suppliant then praises Yahweh in verses 12-13 in optimistic anticipation of the expected salvation.

In their 1993 commentary, Hossfeld and Zenger rightly question whether the terse formulation of verse 4 quoted above can be burdened with such a precise temporal and local extrapolation (Hossfeld \& Zenger 1993:63). According to them, the verbal forms of verse 4 imply that the worshipper simultaneously presents his prayer and sacrifice - he presents his legal problem in the morning and looks forward to Yahweh's legal help, which would not come only by way of a divine judgement in the temple but could include various possibilities of implementation of divine justice in the day-to-day life of the suppliant (Hossfeld \& Zenger 1993:63). ${ }^{3}$ The two references to 'morning' simply evoke the 'morning motif' of the sun god's appearance with its legal-social implication of being saved from legal distress 'in the morning', as this motif had been transferred to Yahweh. ${ }^{4}$ Hossfeld and Zenger nevertheless maintain the view that a legal dispute gave the impetus for the composition of the psalm. ${ }^{5}$

It is indeed true that there are cultic echoes in Psalm 5, but Hossfeld and Zenger also note parallels with the so-called entrance liturgies to the temple in Psalms 15 and 24; a fair number of similarities in form and contents with Psalm 17; and wisdom motifs such as the inclination to instruction in some of the pronouncements about Yahweh (within a prayer directed to him), the doctrine of retribution reflected in verses 11 and 12 and wisdom language such as to 'listen attentively' (קשב hif in v. 3), the

1.To name a few exegetes: Kraus (1978:175), Seybold (1996:40) and Weber (2001:63). Weiser (1962:123) simply classifies it as an 'individual lament' according to its 'form and subject-matter'. Anderson (1972:81) also says it is an individual lament or else a prayer of a falsely accused man. Mowinckel (2014:808) considers Psalm 5 to be a 'sin-offering psalm', which served as a prayer for one who needed cleansing from the effects of sorcerers and demons. There are also those who express doubt that the psalm was intended for such a purpose, for example, Terrien (2003:105). Goldingay (2006:127) asserts that there are no pointers to a specific speaker or context for which it was designed. Prinsloo $(1998: 629$, n. 9) lists the authors who describe the psalm as an individua lament (with some variation, such as that it approaches the quality of a psalm of confidence or of innocence; cf. also Prinsloo 1998:629, n. 10)

2.The description of such a reconstructed cultic interpretation is copied here from Hossfeld and Zenger (1993:63).

3.Van der Ploeg (1973:51-52) has expressed similar precautions against considering the psalm only understandable in the context of a legal case being heard in the temple area.

4.According to Hossfeld and Zenger (1993:63), it is evident in such texts as Genesis 19:15; Hosea 6:5; Zephaniah 3:5; Isaiah 51:4; Psalm 37:6, 101:8; and Job 38:12-15.

5.Hossfeld and Zenger (1993:63): Der Beter legt am Morgen seine Rechtsnot dar und hält Ausschau nach JHWHs Rechtshilfe ... The basis for the plea of the psalmist to be granted justice is, in their view, the supplication at the right point in time and his own cultic suitability (cf. Hossfeld and Zenger 1993:66). 
TABLE 1: The stichometric segmentation of Psalm 5.

\begin{tabular}{|c|c|c|c|c|}
\hline Stanza & Strophe & Verse & Hebrew & Translation \\
\hline & & 1 & 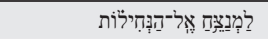 & ${ }^{1}$ To the music director, for playing with flutes. \\
\hline & & & 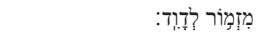 & A Psalm of David. \\
\hline \multirow[t]{7}{*}{1} & A & $2 a$ & 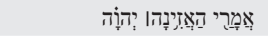 & ${ }^{2}$ Please give ear to my words, Yahweh, \\
\hline & & $\mathrm{b}$ & 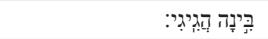 & consider my sighing. \\
\hline & & 3a & 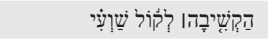 & ${ }^{3}$ Please listen attentively to my cry for help, \\
\hline & & $\mathrm{b}$ & 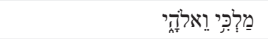 & my king and my God, \\
\hline & & c & 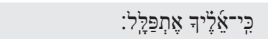 & for to you I pray. \\
\hline & & $4 a$ & 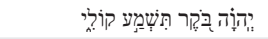 & ${ }^{4}$ Yahweh, in the morning you will hear my voice, \\
\hline & & $\mathrm{b}$ & 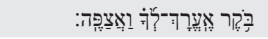 & in the morning, I will present my case to you - and I will wait. \\
\hline \multirow[t]{10}{*}{ II } & $\mathrm{B}$ & $5 a$ & 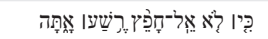 & ${ }^{5}$ For you are not $(-)$ a God who takes pleasure in wickedness, $(-)$ \\
\hline & & $b$ & 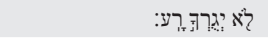 & evil (-) does not dwell with you. (-) \\
\hline & & $6 a$ & 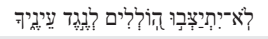 & ${ }^{6}$ Boastful people (-) will not stand before your eyes, $(-)$ \\
\hline & & $\mathrm{b}$ & 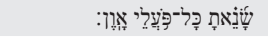 & You hate $(-)$ all the workers of iniquity. $(-)$ \\
\hline & & $7 a$ & 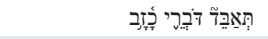 & ${ }^{7}$ You destroy (-) those who speak lies, (-) \\
\hline & $\mathrm{C}$ & $8 a$ & 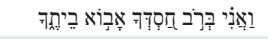 & ${ }^{8}$ But I, through the abundance of your mercy $(+)$, I will come to your house, $(+)$ \\
\hline & & $\mathrm{b}$ & 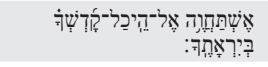 & I will bow down $(+)$ towards your holy temple $(+)$ with awe for you. $(+)$ \\
\hline & & $9 a$ & 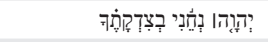 & ${ }^{9}$ Yahweh, lead me $(+)$ in your righteousness $(+)$ \\
\hline & & $\mathrm{b}$ & 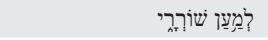 & for the sake of my opponents; \\
\hline & & c & 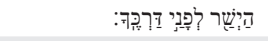 & straighten your way $(+)$ before me. $(+)$ \\
\hline \multirow[t]{10}{*}{ III } & $\mathrm{D}$ & $10 a$ & 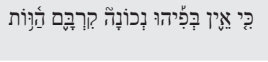 & $\begin{array}{l}{ }^{10} \text { Indeed, there is nothing trustworthy }(-) \text { in their mouth; their inner parts are } \\
\text { destruction, (-) }\end{array}$ \\
\hline & & b & 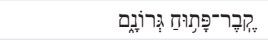 & their throat is an open grave, $(-)$ \\
\hline & & c & 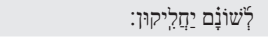 & they flatter (-) with their tongue. \\
\hline & & $11 a$ & 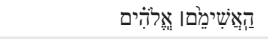 & ${ }^{11}$ Declare them guilty (-) O God, \\
\hline & & $\mathrm{b}$ & 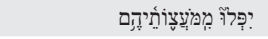 & let them fall (-) by their own counsels. \\
\hline & & c & 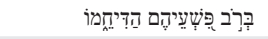 & Because of the abundance of their transgressions $(-)$ drive them out, $(-)$ \\
\hline & & d & 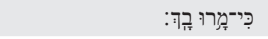 & for they have rebelled (-) against you. \\
\hline & $\mathrm{E}$ & $12 \mathrm{a}$ & 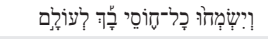 & ${ }^{12}$ But let all those who take refuge $(+)$ in you rejoice forever, $(+)$ \\
\hline & & $13 a$ & 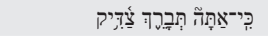 & ${ }^{13}$ For you bless $(+)$ the righteous, $(+)$ \\
\hline & & $\mathrm{b}$ & 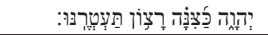 & Yahweh, you surround (+) him with favour (+) as with a shield. (+) \\
\hline
\end{tabular}

'sigh' (הגיג in v. 2) of the suppliant and the verb 'to set out in order' (ערך in v. 4; cf. Job 33:5; 37:19) (Hossfeld \& Zenger 1993:63). Despite the mix between cultic echoes and wisdom features, they view Psalm 5, like Psalm 17, as the supplication of an individual with integrated lament. ${ }^{6}$

This article, in contrast, attempts to interpret Psalm 5 as a composition on its own, not primarily as a prayer of someone who is being prosecuted slanderously. It then explores parallels with the 'prologue' of the Psalter (Ps 1-2) in order to define its present literary purpose. As part of the first group of Davidic prayers in Psalms 3 through 7, the editors also seem to have intended it to be read as a prayer of 'King David' during the time when he fled from Absalom. In such a literary context, the hermeneutic horizon permits a different understanding. It is argued, based on (especially) the parallels with Psalm 1, that the psalm reflects polarisation within the post-exilic community in which the editors worked. Certain unscrupulous members of the Jewish community seem to have exploited their compatriots and to have acted with arrogant disdain for the injunctions of Yahweh's Torah. Psalm 5, it would seem, pronounces a

6.Beide Psalmen sind Bittgebete des einzelnen mit integrierter Klage (Hossfeld \& Zenger 1993:64). The heading for their comments on Psalm 5 describes it as Morgengebet um Rechtshilfe [a morning prayer for legal assistance] (Hossfeld \& Zenger 1993: 63) judgement over these compatriots and intends to encourage a faithful minority by emphasising the advantages and privileges of respectful obedience to the Torah.

\section{Textual and literary analysis of Psalm 5}

See Table 1.

\section{Notes on the text and translation}

4a There is no reason to change תשמע into an imperative in order to continue the series of imperatives in verses $2-3$. $^{7}$

9c The Qere reading הישר, a hiph'il imperative of ישר, is followed.

\section{The segmentation and argumentative thrust of Psalm 5}

The segmentation suggested in the representation above concurs with that of Gert Prinsloo (1998:629). It also coincides with the analysis of Pieter Van der Lugt (2006:119), although

7.Craigie and Tate $(2004: 84)$ do not change the text but translate the form as an imperative. 
TABLE 2: A summary of the structure and contents of Psalm 5.

\begin{tabular}{|c|c|c|c|}
\hline Stanza & Strophe & Verses & Description \\
\hline \multirow[t]{2}{*}{1} & A & $2-3$ & An earnest supplication to Yahweh to listen to the suppliant's prayer. \\
\hline & & 4 & A declaration of trust that Yahweh will listen. \\
\hline \multirow[t]{3}{*}{ II } & B & $5-7$ & $\begin{array}{l}\text { Motivation for the trust in the form of a description of Yahweh's character in which the character of the } \\
\text { opponents is criticised: Yahweh does not tolerate wicked people or criminals: }(-) \times(-)=(+) \text {. }\end{array}$ \\
\hline & $\mathrm{C}$ & 8 & $\begin{array}{l}\text { A declaration of trust that the suppliant, in contrast to the wicked people and criminals, will be granted access } \\
\text { to the temple: }(+) \times(+)=(+) \text {. }\end{array}$ \\
\hline & & 9 & A supplication to be led on Yahweh's way $(+) \times(+)=(+)$. \\
\hline & & 11 & A supplication to Yahweh to declare the transgressors guilty and drive them out: $(-) \times(+)=(-)$. \\
\hline & E & 12 & An inverse supplication to Yahweh to protect those who seek refuge in him and give them joy: $(+) \times(+)=(+)$. \\
\hline & & 13 & A declaration of trust that Yahweh will bless and protect the righteous: $(+) \times(+)=(+)$. \\
\hline
\end{tabular}

he reads verse $6 a$ as two stichs and takes verse $6 \mathrm{~b}$ together with verse 7a as a separate distich. ${ }^{8}$ Van der Lugt (2006:118) describes the contents of the psalm simply as the prayer of an individual according to which the righteous will dwell in God's presence and the evildoers will disappear. There are a few supplicatory sections (vv. 2-3, 9 and 11-12), but the psalm also contains verses that could justifiably be described as declarations of trust (vv. 4, 8 and 13), interspersed between descriptions of the character and actions of evildoers (vv. 5-7, offered in the form of a motivation for the trust on the basis of Yahweh's character; see also vv. 10 and 11d). These descriptions of the evildoers constitute, as it were, the dark background against which the favour and grace of Yahweh for the righteous are highlighted (see Table 2).

Beat Weber's (2001:62) segmentation of strophes (IA, 2-4; IB, 5-7; IIA, 8-9; IIB, 10; IIC, 11; III, 12-13) also agrees with this segmentation, but he finds a division in stanzas (not only strophes) between verses 7 and 8 and verses 10 and 11. In his view, verses 8 and 9 form the centre of the psalm. The structure proposed here demarcates stanza I as an introductory prayer. ${ }^{9}$ Stanza II states that Yahweh cannot associate with or tolerate wicked people or evildoers (strophe $\mathrm{B}$, with six sets of double negatives) but that the suppliant (in contrast) will be granted access to his temple (strophe $C$, with two sets of words with a positive connotation). The suppliant also requests that Yahweh will lead him in his way for the sake of his opponents. His innocence is implied rather than claimed. Stanza III explains how the evildoers bring people to ruin with their words and asks Yahweh to drive them out (presumably from his presence) (strophe D) but to protect the righteous and give them joy in contrast (strophe E).

The dominant theme is therefore the contrast between the actions of evildoers (vv. 5-7; 10), which render them unacceptable before Yahweh, with the favour given to the righteous or sought by them (vv. 8-9; 12-13; in a chiastic arrangement in these two sets) and the privileges and protection they will enjoy as a consequence. It is significant that the psalmist never asserts his own righteousness but instead extols the righteousness of Yahweh (vv. 5-7; 9) and the

8.This may have been the original form, but it refutes the Masoretic punctuation.

9.See also Van der Lugt (2006:118). The name Yahweh forms an inclusion (2a; 4a) and four words from the semantic field of 'listening' separates verses 2 through 4 from the rest of the psalm. Van der Ploeg (1973:52) considers verses 1 through 4 a 'lament', possibly because of the expression הגיג [a whispered lament] in verse 2b. protection he grants to the righteous (v. 13). The psalmist has an earnest desire that Yahweh will expose the wicked, and we know that they are his 'opponents' (9b), but nowhere does he assert that the opponents' actions have affected him directly. ${ }^{10}$ This poses the question whether the psalm can be described as a typical lament ${ }^{11}$ and whether it really fits the generally accepted setting of the psalm as a prayer of someone who has been falsely accused of wrongdoing. It rather seems to express frustration with the unrestrained arrogance with which some members of society take advantage of others and asks Yahweh to expose and expel them.

What are the transgressions of which the opponents are directly or indirectly accused? These include 'wickedness'

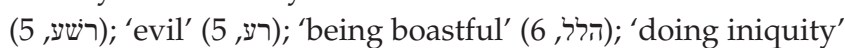

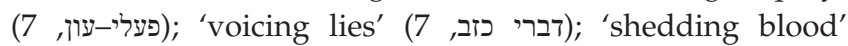
(איש-דמים, 7) (מרמה, 7) 'being or acting deceitful'); people who have nothing 'trustworthy in their mouths' (אין נכונה בפיהו, 10); whose 'inner parts are destruction' (קרבם הוות, 10); wריות (10) whose throat is, metaphorically speaking, an 'open grave' (דברם (גריפתוח) 10 גרונם, and who 'flatter with their tongue' (לשונם יחליקון, 10). They are further accused of harbouring 'counsels' (מערות, 11, (מעונם יחות,); of having an 'abundance of transgressions' (רב פשעיהם, 11); and of having 'rebelled' (מרו, 11) against Yahweh.

\section{What does the author of Psalm 5 ask and how does he do it?}

The most conspicuous feature of Psalm 5 is probably the polarity between the two strophes (B and C) of stanza II. Strophe B not only describes the characteristics of the outgroup but does so with a strong appeal to the righteousness of Yahweh, arguing that Yahweh's holiness could not tolerate the presence of certain classes of sinners, criminals and arrogant people. The focus in strophe B is therefore primarily on Yahweh's righteousness and secondarily on the people with whom he cannot have communion. However, such a description of Yahweh's incompatibility with certain classes of people without doubt serves to pronounce a judgement on

10. Hossfeld and Zenger (1993:64) say that the legal crisis [Rechtsnot] of the psalmist must be inferred from the few concrete indications, referring to Psalm 5:7 and 10 . Wilson says that the phrases used in verses 10 and 11 that the psalmist is suffering malicious attacks and false accusations, but this does not seem to be the case. See malicious attacks and
Wilson (2002:168).

11.Van der Ploeg (1973:51) remarks that Psalm 5 is usually reckoned among the laments. 
them. ${ }^{12}$ This judgement comes later in Psalm 5:11 where the psalmist asks Yahweh to 'declare them guilty'.

Stanza II and strophe B (vv. 5-7) are demarcated from stanza I and strophe A by the noun 'a God' [אל] and the

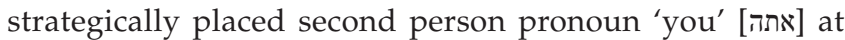
the end of verse $5 \mathrm{a}$. The name Yahweh in verse $7 \mathrm{~b}$ forms an inclusion with this, demarcating the end of strophe B. Strophe C is similarly demarcated from strophe B with the first person singular pronoun and an adversative waw, 'But I' (ואני, v. 8a) at its beginning and a repetition of the name Yahweh at the beginning of verse 9 to demarcate the end of the stanza. Although strophe B is about Yahweh's incompatibility with evildoers, polarity is formed between the unacceptability of these classes of people in strophe B and the acceptability of the suppliant in strophe $C$, because the suppliant is referred to six times in this strophe by the personal pronoun, two first person imperfect forms and three first person pronominal suffixes. At the same time, however, Yahweh is referred to nine times in strophe $C$ (in comparison to the six times in strophe B). The theme of the two strophes can thus be described as the (in) compatibility of specific people with Yahweh's presence. Yahweh's righteousness is specifically mentioned in verse $9 \mathrm{a}$ in the context of the opposition between the suppliant and his opponents, with the implication that all those groups of people mentioned in strophe B also qualify as his personal enemies.

Strophe B is constructed particularly artistically: Three negative statements about Yahweh's incompatibility with unsavoury people are followed by three parallel positive statements about Yahweh's active rejection of the same group of people. In each of these six statements, two negative values or connotations therefore combine to form a positive pronouncement: $(-) \times(-)=(+)$. The transition between the two sets does not coincide with the transition between verses, and this forms a kind of disjunction between the two halves of verse 6 (lending support to Van der Lugt's demarcation mentioned above) (see Table 3).

There is progression from the first set of three statements to the second set, because to not associate with certain people develops into descriptions of Yahweh's positively 'hating', 'destroying' and 'abhorring' this class of characters.

In strophe $C$, no mention is made of the expected claim to innocence or righteousness of the suppliant. Instead, the focus is still on the holiness and righteousness of Yahweh: His holiness comes into play through the mention of the privilege to enter his 'house' (v. 8a) and the parallel reference to his 'holy temple' (v. 8b), which, as the reader knows from strophe $B$, is not accessible to wicked people (see Table 4).

12.As Loader remarks about a similar list of abominations in Proverbs $6.16-19$, it is not necessary for the list to have a conclusion about the negative consequences to which the actions will lead: 'The fact that Yahweh loathes them delivers adequate which the actions will lead: 'The fact that Yahweh loathes them delivers adequate
judgement because it means that such things are incompatible with his being'. See judgement because
TABLE 3: Yahweh's intolerance of the wicked and his rejection of their evil deeds.

\begin{tabular}{|c|c|c|c|}
\hline Verse & Yahweh & Rejection & Groups of people \\
\hline $5 a$ & $\underline{\text { You }}$ are a $\underline{\text { God }}$ & $\begin{array}{l}\text { who does not (-) } \\
\text { take pleasure (חפק) }\end{array}$ & in wickedness (רשעע) (-) \\
\hline $5 b$ & with you & $\begin{array}{l}\text { it does not (-) } \\
\text { dwell (גור) }\end{array}$ & evil (-) (רע) \\
\hline $6 a$ & $\begin{array}{l}\text { before your } \\
\text { eves }\end{array}$ & $\begin{array}{l}\text { they will not (-) } \\
\text { stand (ביצ' hitp) }\end{array}$ & $\begin{array}{l}\text { boastful people (-) } \\
\text { (הלל) }\end{array}$ \\
\hline $6 b$ & You & hate $(-)$ & $\begin{array}{l}\text { all workers of } \\
\text { iniquity }(-)\end{array}$ \\
\hline $7 a$ & $\underline{\text { You }}$ & destroy (-) (אבד pi) & $\begin{array}{l}\text { those who speak } \\
\text { lies (-) }\end{array}$ \\
\hline $7 b$ & Yahweh & abhors (-) & $\begin{array}{l}\text { the deceitful (-) } \\
\text { shedder of blood (-) }\end{array}$ \\
\hline
\end{tabular}

TABLE 4: Yahweh's graceful acceptance of the righteous.

\begin{tabular}{|c|c|c|c|}
\hline Verse & Suppliant & Description & Extension \\
\hline $8 a$ & But I & will enter your house & $\begin{array}{l}\text { through the abundance } \\
\text { of your mercy }\end{array}$ \\
\hline $8 b$ & 1 & $\begin{array}{l}\text { will bow down towards } \\
\text { your holy temple }\end{array}$ & in the fear of you \\
\hline $9 a$ & $\begin{array}{l}\text { Yahweh, } \\
\text { lead me }\end{array}$ & in your righteousness & $\begin{array}{l}9 \mathrm{~b} \text { for the sake of } \mathrm{my} \\
\text { enemies }\end{array}$ \\
\hline $9 c$ & straighten & your way & before me \\
\hline
\end{tabular}

Although there is a polarity between the incompatibility of Yahweh with the various kinds of evildoers described in strophe B and the compatibility of the suppliant with him described in strophe $C$, the focus still is on Yahweh: His house can be accessed through his mercy; in the direction of his holy temple is where the suppliant will bow in his fear; he must lead the suppliant in his righteousness and he must straighten his way before the psalmist. Entrance for the suppliant to the temple is not because of his own holiness but through the 'abundance' of Yahweh's 'mercy' (v. 8a), a probable allusion to the 'formula of grace' in Exodus 34:6 and Numbers 14:18. The last-mentioned verse explains the 'abundance of mercy' as resulting in Yahweh's willingness to forgive 'iniquity and transgression' [עון ופשע]. The 'transgressions' [פשע] of the opponents are specifically mentioned later in verse 11c in the phrase 'the abundance of their transgressions' [ברב פשעיהם]. The 'abundance of mercy' of Yahweh is thus not available or effective for the 'abundance of transgressions' of the opponents.

A striking feature of strophe $C$ is the rhyme that is created by using nouns with possessive suffixes all referring to Yahweh: . חסדך, ביתך, היכל־קדשך, ביראתך, בצדקתך, דרכך 'Your fear' is an objective genitive ('the fear due to you'), while 'your righteousness' is a subjective genitive, 'the fact that Yahweh is righteous'. All that the suppliant says about his own character is that his transgressions are implied to have been forgiven, that he is full of respect for Yahweh and that he would like Yahweh to demonstrate his righteousness by guiding him through life in the presence of his opponents. Verse 9c possibly entails that Yahweh will make the life of the suppliant a little easier in view of the fact that his opponents obstruct his progress. This can be inferred from the request that Yahweh will 'lead' him 'for the sake of his opponents' but also from the contents of strophe D, which focuses on one aspect of the transgressions of the opponents, namely their ability to destroy people with 
their words. ${ }^{13}$ The reference to their 'mouth' and their 'inner parts' in parallel indicate the source of the deception that comes from their mouths. The intention of their 'inner parts', their plans, is revealed through the untrustworthy nature of the words in their mouth. Verse $10 \mathrm{~b}$ contains a metaphor, comparing 'their throat' to an open grave. The implication is again that death lurks inside, and this is explained in verse 10c as the flattering they do with their tongue. They flatter to deceive and they deceive to kill. Verse 11 then summarises the transgressions of the opponents by mentioning their 'counsels' [מעצותיהם] with which they 'transgress' and which constitute 'rebellion' against Yahweh [כי מרו בך]. Three acts of judgement are requested from Yahweh for this: That God would 'declare them guilty'; that they would 'fall by their own counsels', thus into the trap that they have set for others through their words; and that they be 'driven out'.

Strophe E contains a supplication that the righteous people would experience joy and the protection of Yahweh (v. 12) but also a motivation for this in the form of a declaration of trust that Yahweh typically does these things (v. 13). The request for joy is repeated three times: Yahweh should make them 'rejoice forever'; he should 'let them sing for joy'; and he should cause them to 'exult'. The psalmist also asks Yahweh to 'fence off' or 'make inaccessible' (סכך על hifil; like when Moses 'screened off' the Ark of the Covenant) ${ }^{14}$ those who take refuge in him in verse $12 \mathrm{~b}$. This image is possibly meant to recall the access that the righteous persons have to the presence of Yahweh, while the wicked are shut out.

The righteous are described here with two characteristics: They are those who 'take refuge' in Yahweh (12a) and those who 'love' his name (12c). This latter formula sounds like a description from a late phase of post-exilic Yahwism. The motivation for the requests for joy and protection of the righteous reminds the reader of the beginning of strophe B, because both begin with the causal conjunction 'for' ['כ] and both contain the personal pronoun 'you' [אתה] in an address to Yahweh. As in strophe B, the character of Yahweh is also described in verse 13. However, in contrast to strophe B, where his abhorrence of criminals is described, verse 13 describes Yahweh's care for the righteous: He 'blesses' him [ ברך] pi] and he 'covers' or 'surrounds' [עטר] him with 'favour' [רצון] as with a shield. This simile suggests that Yahweh's 'favour' or 'delight' [רצון] acts like the 'long' or 'body shield' [צנה] and does that which the psalmist asks for in verse $12 \mathrm{~b}$, namely to 'screen off' the righteous.

Prinsloo (1998:637) correctly summarises the parallel structure between strophes $\mathrm{B}$ and $\mathrm{C}$ with strophes $\mathrm{D}$ and $\mathrm{E}$ as follows:

a A (2a-4b) Prayer by a righteous sufferer

$b$ B (5a-7b) No place for the $b^{1} D(10 a-11 d)$ Destruction of wicked

the wicked

c C (8a-9b) Always a place $\quad c^{1}$ E $(12 a-13 b)$ Protection of

for the righteous the righteous.

\section{Psalm 5 as a literary composition intended to reflect the ideology of Psalms 1 and 2 and the character of David in Psalms 3 and 4}

Could Psalm 5 possibly be the supplication of someone who has been falsely accused and who now approaches Yahweh (or his temple officials) for help? Psalm 5:4 does refer to the suppliant's 'presenting his case' in the 'morning' and 'waiting' for a response. This 'presenting' could also refer to the arrangement of the arguments of the psalmist, however, and does not necessarily imply an accompanying sacrifice. It is also true that the psalmist lists 'lies' as one of the sins of his opponents (v. 7) and goes on to explicate their false statements (v. 10a), which could destroy and kill (v. 10a-b) because they 'flatter' (חלק hif, v. 10c). 'Lies' and 'false' statements fit in with the idea of someone falsely accused but 'flattering' does not. Proverbs 29:5, however, indicates that 'flattering' should be interpreted within a context of deception with the purpose to defraud someone. ${ }^{15}$

The transgressions of the opponents are, however, described in the first place not as a transgression against the palmist but as offensive to Yahweh because of his holiness (he 'hates' it and 'abhors' it). These sins constitute a comprehensive list of abominations rather than specific charges of deceit as one would expect from a person falsely accused. The suppliant does not ask but confidently states that people who commit these sins would be denied access to Yahweh. His own innocence also does not seem a matter of concern to him, but he seems to focus rather on the safety and happiness of all the members of the in-group. The juxtaposition of verses 11 and 12 could suggest that the joy of the righteous would be greatest when these people who rebel against Yahweh are declared guilty, punished by their own schemes and 'driven out'.

However, what seems to be a more important objection against a strict cultic interpretation are the traces of wisdom thinking in the psalm and the similarities Psalm 5 has with Psalm 1. A list of things that constitute 'abominations' to Yahweh is a specific characteristic of Proverbs. ${ }^{16}$ Psalm 5 seems, as a matter of fact, to have been composed (or extensively edited) to display similarities with Psalm 1 as well as links with Psalm 2, so that one could say it was groomed for exactly this position in the Psalter. If this is the case, then exegetes will have to rethink the current views on its date of origin and the time when the 'prologue' was attached to the first cluster.

Gianni Barbiero (1999:76-77) has noted and neatly tabulated the various connections between Psalm 5 and Psalm 1. He has noted the links between the 'wicked people' [רשעים] in

15.Proverbs $29: 5$, A man who flatters his neighbour is spreading a net for his footsteps'

16.See Proverbs $11: 1,20 ; 12: 22 ; 15: 8 ; 16: 5 ; 17: 15 ; 20: 10 ; 29: 9$. The list is provided by Loader (2014:269, n. 46). In four of these verses ( $\operatorname{Pr} 11: 1,20 ; 12: 22$ and 15:8), the 'abomination' is contrasted with something that is a 'delight' [רצ] to Yahweh. Note Psalm 5:13b for Yahweh's רצון. 
Psalm 1:1, 4, 5 and 6 and 'wickedness' [רשע] in Psalm 5:5; the 'counsel of the wicked' [עצת רשעים] in 1:1 and 'their counsels' [those of the wicked, מעצותיהם] in 5:11; the 'delight' [חפעם] of the righteous in 1:2 and Yahweh's lack of 'delight' in wickedness in 5:5; the 'righteous persons' [צדיקים] in 1:5 and 6 and the 'righteous person' [צדיק] in 5:13; the fact that the road of the wicked will 'perish' [אבד] in 1:6 and the note that Yahweh will 'destroy' [ אבד pi] the liars in 5:7; and the two instances of 'road' [דרך] in 1:6 and the reference to Yahweh's 'road' [דרך] in 5:9. He says that the road imagery that characterises Psalm 5 reminds one of Psalm 1, where the two roads, those of the ציקים and are introduced programmatically and he then states that the judgement about which Psalm 1:5 speaks finds place in Psalm 5 at the door of the temple (Barbiero 1999:76). He thus sees an editorial linking of the two psalms but would probably not go so far as to claim that the author of Psalm 5 alludes to Psalm 1.

To the reader who is acquainted with Psalm 1, the parallels between Psalms 1 and 5 seem more than superficial or coincidental. The three statements about things and people with which Yahweh has no association in Psalm 5:5ab and 6a are strongly reminiscent of the three groups of people with which the 'blessed person' of Psalm 1:1 has no association (see Table 5).

In addition to the threefold repetition of the negative particle לא and its intention to emphasise the lack of communion with certain sins or persons committing them, the ideas of

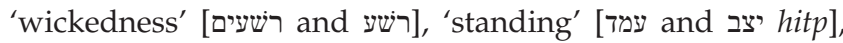

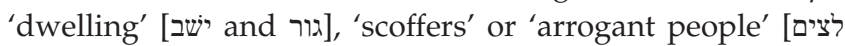

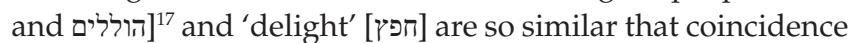
can be ruled out. In fact, it seems that the author or editor of Psalm 5 made a conscious effort to refer to the opening lines of Psalm 1 without making it too obvious that he is alluding to Psalm 1. As the righteous person does not 'stand' [עמד] with sinners on the road of life, ${ }^{18}$ so arrogant people will not 'take a stand' [יצב hitp] before the eyes of Yahweh. As the righteous person does not 'dwell' [ישב] with scoffers, so evil will not 'stay' [גור] with Yahweh. As the righteous person 'delights' in the Torah of Yahweh, so Yahweh does 'not delight' in wickedness. His delight (or 'favour', רצון), instead, is with the righteous according to Psalm 5:13. ${ }^{19}$ The opponents of Psalm 5 are later also criticised for their 'counsel'; the suppliant of Psalm 5 asks Yahweh to guide him on Yahweh's 'road' as Psalm 1 says that Yahweh 'knows' the road of the righteous; and as the road of the wicked will 'perish', according to Psalm 1:6, so Yahweh 'destroys' those who lie in Psalm 5:7a. It is difficult to imagine that these links were only later inserted by the editors of the Psalter. Psalm 5:5

\footnotetext{
17. Koehler and Baumgartner (1994-2000 entry 2293) simply list to 'be infatuated" as the meaning of the qal of הלל Some element of the po'el's meaning must be present in the qal, however, and many translations of this verse and Psalm 73:3, where the form is also used, reflect this 'arrogance' or 'proudness' (e.g. the ESV and NET). Concerning the לצים, Proverbs 3:24 uses this word for 'scorners' 'scoffers' in an antithetic parallel with 'humble people'. Arrogance is therefore certainly involved.

18.And the wicked, conversely, will not 'stand up' [לא יקומו] in the gathering of the righteous (1:5)

19.See the contrast between Yahweh's תועבה and his רצון in Proverbs 11:1, 20; 12:22; and 15:8.
}

TABLE 5: The similarities between Psalm 1 and Psalm 5.

\begin{tabular}{|c|c|c|c|}
\hline Verse & $\begin{array}{l}\text { Description of } \\
\text { righteous }\end{array}$ & Verse & Description of Yahweh \\
\hline $1: 1 a$ & 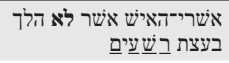 & $5: 5 a$ & לא אל־חפצ רבשׁע אתה \\
\hline b & ובדרך חטאים לא & $b$ & לא יגרך רע \\
\hline c & ובמושב לצים לא ישב & $6 a$ & 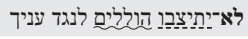 \\
\hline $2 a$ & כי אם בתורת יהוה חפצו & - & - \\
\hline
\end{tabular}

through 9, the complete second stanza and possibly the whole psalm must have been composed by someone who had had access to Psalm 1.

However, Psalm 5 has also been linked by the editors to Psalm 2. Barbiero (1999:77) notes the repetition of eight words or phrases and says that the themes connecting the two psalms are primarily the connection with the temple and Zion theology and further the confrontation in both psalms with the enemies of Yahweh and his anointed. The suppliant of Psalm 5 is, after all, David, the anointed (5:1). He further states that the contrast between 2:2 and 5:6 is conspicuous: The kings of the earth 'take a stand' [יתיצבו] against Yahweh and his anointed (2:2), but 5:6 responds by stating that the wicked will not be able to 'withstand' [לא-יתיצבו] Yahweh. He

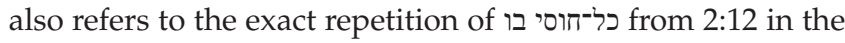
phrase כל־חוסי בך 5:12, in both instances at the end of the psalm. These similarities could certainly be the result of the process of editing. The link between יתיצבו in 2:2 and 5:6 may

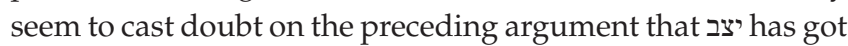
a link with עמד in Psalm 1:1, but it is also possible that the intention was to refer to both Psalm 1 and Psalm 2, to the first in a thematic way and to the second by repeating an exact form of a verb. It should be remembered that both the phrases in Psalm 1:1 together also form a polarity with לא יקומו in Psalm 1:5 (as the righteous does not 'stand' or 'sit/dwell' with the wicked, so the wicked will not 'stand up' or 'rise' in judgement or in the company of the righteous). The inability of the wicked to 'rise' in judgement in Psalm 1:5 is, in turn, directly linked to the 'uprising' of the kings and rulers in Psalm 2:2, an action that is doomed according to Psalm 1:5, and this judgement is confirmed by Psalm 5:6. In addition to the thematic links mentioned by Barbiero between Psalm 5 and Psalm 2, there is also the description of the opponents as having 'rebelled' [מרו] against Yahweh, an allusion to the rebellion in Psalm 2:2 but also to the 'uprising' [קמים] of the 'many' in Psalm 3:2.

As Psalm 1 seems to have been composed by someone with a knowledge of Proverbs, especially Pr 1-2, so Psalm 5 also reflects wisdom themes and probably also knowledge of Proverbs. Bernard Gosse (2008:59) finds specific influence of Proverbs 10:29 and 21:15 in Psalm 5:6 and further also influence of Proverbs 6:16-19 in Psalm 5:7. In particular, the seven things that Yahweh 'hates' [שנא, Pr 6:16; Ps 5:6] and 'abhors' [תועבה, Pr 6:16; cf. תעב pi in Ps 5:7] mentioned in Proverbs 6:16-19 show correspondence to and possible seminal influence in Psalm 5:5-7. 'Haughty eyes', a 'lying tongue' [לשון שקר], 'hands that shed innocent blood' [דם], 'a heart that devises wicked [און] plans', 'feet that run to do evil' 
[רעה], 'lies' [כזבים] and the person who 'sows discord' are mentioned. The theme of Yahweh's disgust with these things and the teaching style adopted in Psalm 5:5-7 are certainly noteworthy and point at least towards a shared milieu.

However, the parallels with the Torah wisdom Psalm 1 are possibly even more important. The author of Psalm 5 probably had an example of a list of 'abominations' in Pr 6:16-19. However, the threefold negative formulation in Psalm 5:5-6a of things in which Yahweh does not find delight before the typical formulation of the list begins in verses $6 \mathrm{~b}$ and 7 cannot be understood as anything but an obscure allusion to Psalm 1:1-2. If these parallels are correctly identified in this article, it would mean that the purpose of Psalm 5 was not to provide a liturgical prayer for use by someone who is innocently accused of some transgression. Its purpose would rather be to give instruction like Psalm 1 does. Because Yahweh's character is incompatible with (לכ) ברב) (צו (צi) the wicked and because he finds delight) חסד, רצון, v. 13b) in the righteous (צדיק), therefore the righteous will be blessed (ברך pi), will have communion with Yahweh in his temple (בוא, חוה histaf) and will experience his guidance

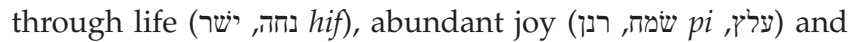
Yahweh's protection (סכך על, עטר).

As a prayer of 'David', who was persecuted by his son and a multitude (רב, רבב Psalm 3:2, 3; 4:7) of rebels (צום , קום hitp Psalm 1:5; 2:2; 3:2; 5:6), Psalm 5 demonstrates his own commitment to find delight only in the presence, guidance and protection of Yahweh, because his unjust persecutors would not prevail. David's hope of returning to Jerusalem and being in the presence of Yahweh again (cf. 2 Sam 15:25) was based on his realisation that the wicked will not be tolerated in the presence of Yahweh. He could pray that the lies of his opponents be exposed, because they had not only rebelled against him, the anointed of Yahweh, but against Yahweh himself $(2: 2 ; 5: 6,11)$. Because he took refuge in Yahweh $(2: 12 ; 5: 12)$, he would be screened off $(3: 4 ; 5: 12,13)$ and would once again rejoice and exult $(4: 8$; $5: 12)$ in God.

The person who composed or edited this psalm and who knew Proverbs 16 and Psalms 1-2, as well as Psalms 3-4, very well must have lived in a time when the distinction between those who were righteous and those who were wicked was not so clear. As a righteous person, who believed that Yahweh would not tolerate the exploitation of his fellow upright Jews, he composed this psalm to exhort them to faithful humility and respect for Yahweh, to trust in Yahweh because he would straighten their road of life and give them joy again, joy that probably was in short supply at the time.

\section{Conclusion}

Psalm 5:5-9 must have been composed by someone who was an accomplished poet and theologian. Psalm 5:5-7 constitutes an invective against evildoers in the style of the abomination list found in Proverbs 6:16-19 but created in such a way that it reflects contact with and forms a parallel to Psalm 1:12. As a prayer of 'David' in its present position, it also displays links with Psalm 2 and fits neatly into its present position after Psalms 3 and 4. In this literary position, it constitutes an instruction to the readers of the Psalter to remember that wickedness is incompatible with the character of Yahweh and that only those who live in close association with Yahweh and his Torah will find happiness and safety. ${ }^{20}$ The insincere, arrogant or irreligious members of the community who exploited their compatriots would be exposed and punished by Yahweh.

\section{Acknowledgements}

The author would like to acknowledge the input of his retired colleague and friend, J. Henk Potgieter, with whom the topic was discussed on numerous occasions during the research and composition of the article.

\section{Competing interests}

The author declares that he has no financial or personal relationships which may have inappropriately influenced him in writing this article.

\section{References}

Anderson, A.A., 1972, The book of Psalms. Volume I: Psalms 1-72, The New Century Bible Commentary, Wm. B. Eerdmans, Grand Rapids, MI.

Barbiero, G., 1999, Das erste Psalmenbuch als Einheit: Eine synchrone Analyse von Psalm 1-41, Österreichische Biblische Studien 16, P. Lang, Frankfurt am Main.

Craigie, P.C. \& Tate, M.E., 2004, Psalms 1-50, Word Biblical Commentary 19, Nelson Reference \& Electronic, Nashville, TN.

Goldingay, J., 2006, Psalms, volume 1: Psalms 1-41, Baker Commentary on the Old Testament, Wisdom and Psalms, Baker Academic, Grand Rapids, MI.

Gosse, B., 2008, L'influence du livre des Proverbes sur les rédactions bibliques à l'époque Perse, Supplément no 14 à Transeuphratène, Gabalda, Paris.

Hossfeld, F. \& Zenger, E., 1993, Die Psalmen I: Psalm 1-50, Die Neue Echter Bibel, Echter, Würzburg.

Koehler, L. \& Baumgartner, W., 1994-2000, The Hebrew and Aramaic Lexicon of the Old Testament. (HALOT), electronic version, revised by W. Baumgartner and J.J. Stamm with assistance from B. Hartmann, Z. Ben-Hayyim, E. Y. Kutscher and P. Reymond, translated and edited under the supervision of M.E.J. Richardson, Koninklijke Brill, Leiden.

Kraus, H.-J., 1978, Psalmen 1-59, Biblischer Kommentar zum Alten Testament, Neukirchener Verlag, Neukirchen-Vluyn.

Loader, J.A., 2014, Proverbs 1-9, Historical Commentary on the Old Testament, Peeters, Leuven.

Mowinckel, S., 2014, Psalm studies, vol. 2, transl. M.E. Biddle from the 1921-1924 publication Psalmenstudien, History of Biblical Studies 3, SBL Press, Atlanta, GA.

Prinsloo, G.T.M., 1998, 'Psalm 5: A theology of tension and reconciliation', Skrif en Kerk $19,628-643$.

Seybold, K., 1996, Die Psalmen, Handbuch zum Alten Testament I/15, J.C.B. Mohr, Tübingen.

Terrien, S., 2003, The Psalms: Strophic structure and theological commentary, The Eerdmans Critical Commentary, Eerdmans, Grand Rapids, MI.

Van der Lugt, P., 2006, Cantos and strophes in biblical Hebrew poetry: With special reference to the first book of the Psalter, Brill, Leiden.

Van der Ploeg, J.P.M., 1973, PsalmenÖ Deel 1, Psalm 1 t/m 75, De Boeken van het Oude Testament, J. J. Romen \& Zonen, Roermond.

Weber, B., 2001, Werkbuch Psalmen: Die Psalmen 1 bis 72, Kohlhammer, Stuttgart.

Weiser, A., 1962, The Psalms: A commentary, translated from the 1959 fifth revised edition of Die Psalmen by H.H. Hartwel, Old Testament Library, SCM Press, London.

Wilson, G.H., 2002, Psalms volume I, New International Version Application Commentary, Zondervan, Grand Rapids, MI.

20.As Craigie formulates it, "the prayer is not only for protection from wicked persons, but also a prayer for protection from becoming like them'. See Craigie and Tate (2004:89). 